\title{
Atypical recurrent varicella in 4 patients with hemopathies
}

\author{
Arjen F. Nikkels, MD, PhD, ${ }^{\mathrm{a}}$ Thierry Simonart, MD, ${ }^{\mathrm{b}}$ Alain Kentos, MD, ${ }^{\mathrm{c}}$ Corinne Liesnard, MD, ${ }^{\mathrm{d}}$ \\ Catherine Sadzot-Delvaux, PhD, ${ }^{\mathrm{e}}$ Walter Feremans, $\mathrm{MD}, \mathrm{PhD},{ }^{\mathrm{c}}$ and Gérald E. Piérard, $\mathrm{MD}, \mathrm{PhD}^{\mathrm{a}}$ \\ Liège and Brussels, Belgium
}

\begin{abstract}
Relapsing varicella may occur in children with HIV infection and more rarely in younger adults. Our aim was to report unusual clinical, histologic, and virologic aspects of 4 elderly patients with malignant hemopathies who had an unusual form of recurrent varicella develop. Conventional microscopy, immunohistochemistry, and in situ hybridization were applied to smears and skin biopsy specimens. The patients presented a few dozen, scattered, large, papulovesicular lesions with central crusting. No zoster-associated pain or dermatomal distribution of the lesions was noted. Conventional microscopy revealed vascular changes and epidermal alterations typical for $\alpha$-herpes virus infection. The varicella zoster virus major viral envelope glycoproteins $\mathrm{gE}$ and $\mathrm{gB}$, and the immediate-early varicella zoster virus IE63 protein and the corresponding genome sequence for gE were detected on Tzanck smears; they were localized in endothelial cells and keratinocytes on skin biopsy specimens. The varicella zoster virus infection in endothelial cells, the vascular involvement, and the widespread distribution of the lesions suggest that the reported eruptions are vascular rather than neural in origin. These findings invalidate the diagnosis of herpes zoster but strongly support the diagnosis of recurrent varicella in an indolent and yet unreported presentation. Furthermore, these eruptions differ from relapsing varicella in children and young adults by the age of the patients, the paucity of clinical lesions, the larger diameter of the lesions and their peculiar clinical aspect, the significantly longer time interval between primary varicella and the recurrence, the prolonged healing time of the lesions, their mild disease course, and the fact that all the lesions are in the same stage of development. (J Am Acad Dermatol 2003;48:442-7.)
\end{abstract}

$\mathrm{T}$ he first contact with varicella zoster virus (VZV) leads to an infection of the upper respiratory airways, followed by a primary viremia that remains clinically silent. This primary viremia is halted by the nonspecific immune defense mechanism of the host. Subsequently, viral replication occurs in the liver, spleen, and probably other organs. This viral replication is then followed by a massive release of viral particles in the bloodstream. This secondary viremia finally leads to the invasion of cutaneous tissues and the development of typical varicella skin lesions. ${ }^{1,2}$ Subsequently, the virus remains in a latent state in the dorsal root ganglia, where specific VZV protein expression takes

\footnotetext{
From the Departments of Dermatopathology ${ }^{\mathrm{a}}$ and Fundamental Virology, ${ }^{d}$ University Medical Center of Liège; and the Departments of Dermatology, ${ }^{\mathrm{b}}$ Hematology, ${ }^{\mathrm{c}}$ and Virology, ${ }^{\mathrm{e}}$ Erasme University Medical Center.

Supported by a grant from the Belgian Fonds de la Recherche Scientifique Médicale to Drs Nikkels and Piérard.

Reprint requests: Arjen F. Nikkels, MD, PhD, Department of Dermatopathology, CHU Sart Tilman, B-4000 Liège, Belgium. E-mail: af.nikkels@chu.ulg.ac.be.

Copyright $\odot 2003$ by the American Academy of Dermatology, Inc. 0190-9622/2003/\$30.00+0

doi: $10.1067 / \mathrm{mjd} .2003 .94$
}

place. ${ }^{3-5}$ During varicella, there is a usual seroconversion with the development of specific anti-VZV IgM and IgG antibodies. The progressive fading of the specific IgM antibodies leads to the classic $\mathrm{IgG}^{+}$, $\mathrm{IgM}^{-}$status proving past varicella infection..$^{1,2}$ On reactivation, the virus usually migrates from the dorsal root ganglia along axons to the skin where it produces a cytolytic infection in the keratinocytes resulting in shingles. ${ }^{6,7}$

In the otherwise normal population herpes zoster and varicella usually occur each as single episodes. In patients who are immunocompromised relapsing shingles, ${ }^{8}$ other atypical VZV-related cutaneous infections, ${ }^{9-12}$ and recurrent VZV retinitis ${ }^{13}$ have been described. Recurrent varicella has also been reported in children infected with HIV and in children with cancer.9,10,14-18 Although exceptional, relapsing varicella has been described in young adults with HIV infection ${ }^{19,20}$ or neoplasia. ${ }^{21}$ In such patients, lesions may affect many organs with devastating morbidity and even mortality.7,22 Primary varicella infection and its recurrent type in children and young adults are clinically indistinguishable, $, 9,10,14-21$ but are serologically different as the first is associated with seroconversion and the latter possesses a $\mathrm{IgG}^{+}, \mathrm{IgM}^{-}$status of past primary varicella infection. 
Table I. Patient characteristics

\begin{tabular}{|c|c|c|c|c|}
\hline $\begin{array}{l}\text { Patient } \\
\text { No. }\end{array}$ & Age $(y) /$ Sex & Hemopathy & $\begin{array}{c}\text { Chemotherapeutic } \\
\text { regimen }\end{array}$ & $\begin{array}{l}\text { Time interval between the last } \\
\text { chemotherapy course and the } \\
\text { appearance of lesions }\end{array}$ \\
\hline \multirow[t]{2}{*}{1} & $40 / \mathrm{M}$ & Chronic lymphocytic leukemia & $\begin{array}{l}\text { 1. Chlorambucil and } \\
\text { methylprednisolone }\end{array}$ & $2 \mathrm{mo}$ \\
\hline & & & 2. Dexa-beam & 5 days, 2 mo \\
\hline 2 & $65 / M$ & Multiple myeloma lgG $\kappa$ type & VPMC ( 1 course) & 4 wks \\
\hline 3 & $70 / \mathrm{M}$ & Multiple myeloma $\lg A \kappa$ type & VPMC (5 courses) & 20 days \\
\hline 4 & $86 / F$ & Chronic neutrophilic leukemia & Hydroxyurea & Unknown \\
\hline
\end{tabular}

Dexa-beam, Dexamethasone, carbustine, etoposide, cytarabine, and melphalan; VPMC, vincristine, prednisolone, melphalan, and cyclophosphamide.

The purpose of this article is to describe the clinical, histologic, and virologic features of 4 elderly patients who exhibited an unusual type of recurrent varicella after chemotherapy for malignant hemopathies. One of the patients experienced 3 such relapses.

\section{MATERIAL AND METHODS Clinical presentation}

The clinical characteristics are reported in Table I. Serologic status of past VZV and herpes simplex virus (HSV) infections (IgM-, IgG +), as determined by enzyme-linked immunosorbent assay, was known for all the patients before the occurrence of the presently reported eruptions.

\section{Laboratory examinations}

Microscopy. Smears were collected from patients 1, 2, and 4 on silanized glass slides. One smear was stained for 1 minute with a toluidine blue and basic fuchsin solution (polychrome multiple stain, Delasco, Council Bluffs, Iowa). ${ }^{20}$ Other smears were used for immunohistochemistry.

Skin biopsies were obtained from patients 2, 3, and 4 from the periphery of the lesions under local anesthesia with lidocaine $1 \%$ and $1 / 10^{6}$ adrenalin. The samples were formalin-fixed (neutralized formalin 10\%) and paraffin-embedded for routine processing. A $5 \mu \mathrm{m}$-thick section was stained with hematoxylin and eosin. Other sections were prepared on silanized slides for immunohistochemistry and in situ hybridization.

Viral culture. In patient 1 viral isolation was obtained on culture. Subsequent immunofluorescence identification on viral culture was performed using a mouse monoclonal anti-VZV antibody (Argene Biosoft, Varilhes, France). Anti-HSV antibodies were included as controls.

Immunohistochemistry. In patients 2,3 , and 4 immunohistochemistry using the labeled streptavidin-biotin method was performed on smears and
Table II. Clinical characteristics of the lesions

\begin{tabular}{lclc}
\hline $\begin{array}{l}\text { Case } \\
\text { No. }\end{array}$ & $\begin{array}{c}\text { Approximate } \\
\text { No. of lesions }\end{array}$ & \multicolumn{1}{c}{ Anatomic sites } & $\begin{array}{c}\text { Healing } \\
\text { time (days) }\end{array}$ \\
\hline 1 & Episode 1: 40 & Trunk, scalp, limbs & 13 \\
& Episode 2: 10 & Head, abdomen, limbs & 12 \\
& Episode 3: 10 & Limbs, R foot & 10 \\
2 & 20 & Trunk, R arm & 9 \\
3 & 30 & L arm, trunk, face & 14 \\
4 & 20 & Entire tegumentum & 12 \\
\hline
\end{tabular}

skin biopsies after a previously described protocol. ${ }^{23,24}$ The mouse monoclonal anti-VZV antibodies VL8 and VL2 were used to detect the envelope glycoproteins $\mathrm{gE}$ and $\mathrm{gB}$, respectively. ${ }^{23}$ The rabbit polyclonal antibody anti-IE63 was also included. ${ }^{4} \mathrm{~A}$ rabbit polyclonal anti-HSV I antibody (Dakopatts, Glostrup, Denmark) was also used on smears and biopsies. Primary antibody omission and immunostaining on normal skin served as controls.

In situ hybridization. In situ hybridization was carried out on biopsies from patients 2, 3, and 4 as described previously. ${ }^{23}$ The 16.6-kilobase EcoRI-A restriction endonuclease fragment of VZV DNA, corresponding to gE, and an anti-HSV probe (Enzo Diagnostics, New York, NY) were used to detect viral DNA in the biopsy specimens. The usual controls were included.

\section{RESULTS \\ Clinical presentation}

Table II summarizes some clinical aspects of the skin lesions. They consisted of large $(1-4 \mathrm{~cm})$, welldemarcated, isolated, vesiculopapular lesions with central crusting or necrosis (Fig 1, $a$ through $d$ ). No dermatomal clustering of the lesions, indicating herpes zoster, could be evidenced. Prodromal and concomitant pain was not experienced by the patients. Only patient 1 had mild headache, fever, and arthralgia during the first recurrent episode. Secondary 


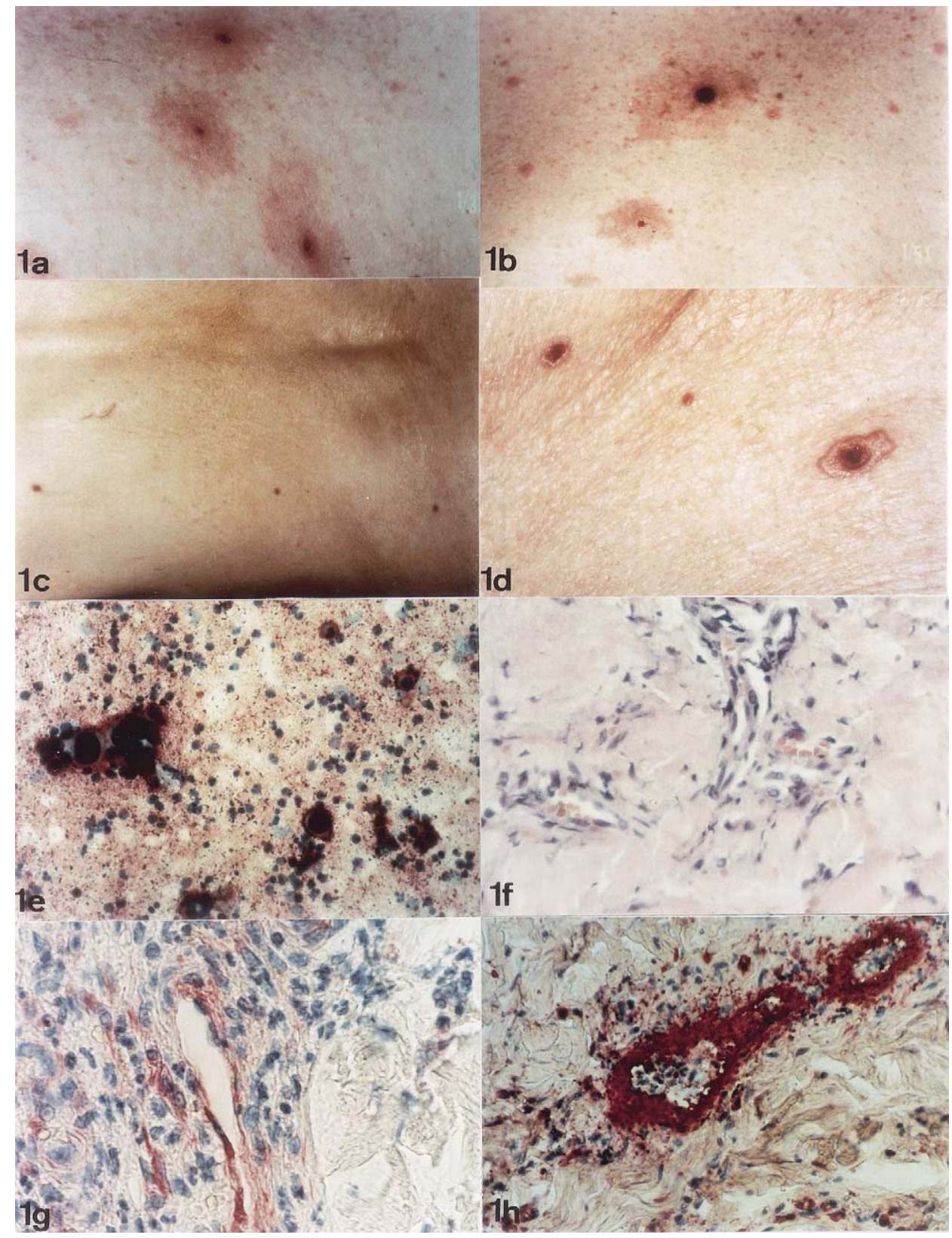

Fig 1. a, Scattered large erythematopapular lesions with central crusting on the abdomen (patient 1). b, Large erythematopapular lesions on a limb (patient 1). c, Large lesion on the arm (patient 3). d, Three large erythematopapular lesions on the back (patient 2). e, Immunohistochemic detection (red signal) of the gE VZV envelope glycoprotein on a Tzanck smear (Mab VL8; original magnification $\times 100$ ). $\mathbf{f}$, Vascular changes with swollen endothelial cells (hematoxylin-eosin stain; original magnification $\times 100$ ). $\mathbf{g}$ and $\mathbf{h}$, Immunostaining (red signal) demonstrating the gE VZV protein in endothelial cells, illustrating the viral vasculitic alterations (Mab VL8; original magnification $\times 100$ ).

hypopigmented varioliform scars were noted in patients 1, 2, and 4. Patients 2, 3, and 4 experienced a single recurrent episode without any evidence of herpes zoster lesions. Patient 1 presented 3 relapses of such atypical varicelliform lesions. On diagnosis all the patients were treated with intravenous acy- clovir (Zovirax, Glaxo Wellcome, London, UK) (10 $\mathrm{mg} / 8 \mathrm{~h}$ for $8-10$ days). As a result of the recurrent character of the lesions, after the third relapse patient 1 received a prophylactic antiviral regimen with oral valacyclovir (Zelitrex, Glaxo Wellcome) $(4 \times$ $500 \mathrm{mg}$ daily) for 10 months, after which the treat- 
Table III. Results of smears, viral culture, VZV serology immunohistochemistry, and in situ hybridization

\begin{tabular}{|c|c|c|c|c|c|c|c|}
\hline Case & $\begin{array}{l}\text { Smear } \\
\text { cytology } \\
\text { (PMS) }\end{array}$ & $\begin{array}{l}\text { Smear } \\
\text { IHC, IF }\end{array}$ & $\begin{array}{c}\text { Culture } \\
\text { IF }\end{array}$ & $\begin{array}{c}\text { Anterior VZV } \\
\text { serology status }\end{array}$ & $\begin{array}{c}\text { Biopsy histology } \\
\alpha \text {-herpes virus } \\
\text { infection features }\end{array}$ & $\begin{array}{l}\text { Biopsy IHC: } \\
\text { gE, gB,IE63 }\end{array}$ & $\begin{array}{c}\text { Biopsy ISH: } \\
\text { EcoRI-A }\end{array}$ \\
\hline 1 & $\alpha$-Herpes & VZV IF + & VZV+ & $\lg G+, \lg M-$ & NA & NA & NA \\
\hline 2 & $\alpha$-Herpes & $\begin{array}{c}\mathrm{gE}, \mathrm{gB}, \mathrm{IE} 63 \\
\mathrm{IHC}+\end{array}$ & NA & $\lg G+, \lg M-$ & $\begin{array}{c}\text { KC: }+ \\
\text { Vasculitis: + }\end{array}$ & $\begin{array}{l}\mathrm{KC}:+ \\
\mathrm{EC}:+\end{array}$ & $\begin{array}{l}\mathrm{KC}+ \\
\mathrm{EC}:+\end{array}$ \\
\hline 3 & NA & NA & NA & $\lg G+, \lg M-$ & $\begin{array}{c}\text { KC: }+ \\
\text { Vasculitis: }+\end{array}$ & $\begin{array}{l}\mathrm{KC}:+ \\
\mathrm{EC}:+\end{array}$ & $\begin{array}{l}\mathrm{KC}:+ \\
\mathrm{EC}:+\end{array}$ \\
\hline 4 & $\alpha$-Herpes & $\begin{array}{c}\mathrm{gE}, \mathrm{gB}, \mathrm{IE} 63 \\
\mathrm{IHC}+\end{array}$ & NA & $\lg G+, \lg M-$ & $\begin{array}{c}\text { KC: }+ \\
\text { Vasculitis: }+\end{array}$ & $\begin{array}{l}\mathrm{KC}:+ \\
\mathrm{EC}:+\end{array}$ & $\begin{array}{l}\mathrm{KC}:+ \\
\mathrm{EC}:+\end{array}$ \\
\hline
\end{tabular}

$\alpha$-Herpes, Typical cytologic features of $\alpha$-herpesvirus infection; $E C$, endothelial cell; IF, immunofluorescence; IHC, immunohistochemistry; ISH, in situ hybridization; $K C$, keratinocyte; $N A$, not available; $P M S$, polychrome multiple stain.

ment was interrupted without further recurrence of the lesions.

\section{Laboratory results}

The synoptic Table III summarizes the results of smears, viral culture, VZV serology, immunohistochemistry, and in situ hybridization for every patient.

Microscopy. Smears of patients 1, 2, and 4 supported the cytologic diagnosis of $\alpha$-herpesviridae infection by the presence of multinucleated syncytial cells with ground glass-appearing nuclei. Histologic examination of the biopsies from patients 2, 3, and 4 revealed intraepidermal vesiculation containing multinucleated giant keratinocytes, and a mixed lymphoneutrophilic infiltrate. Such alterations were typical for $\alpha$-herpes virus infection. Furthermore, significant vascular changes were present including endothelial cell swelling and red blood cell extravasation (Fig 1, $f$ ).

Immunohistochemistry. In patient $1 \mathrm{VZV}$ was identified in the smear and viral culture using immunofluoresence. A positive immunohistochemic signal for VZV was evidenced on the Tzanck smears of patients 2 and 4 (Fig 1,e). Anti-HSV I antibodies gave negative results on the smears. Immunohistochemic testing of the skin biopsies of patients 2, 3, and 4 revealed the presence of VZV gE, gB, and IE63 proteins in epidermal keratinocytes and dermal dendritic cells. These VZV components were also present in endothelial cells at the site of vasculitic changes (Fig 1, $f$ and $b$ ). VZV immunostaining was not observed in cutaneous nerves. The primary antibody omission, the anti-HSV I antibody, and immunostaining on normal skin yielded negative results.

In situ hybridization. In situ hybridization using the anti-VZV EcoRI-A probe yielded positive results in the skin biopsies of patients 2,3 , and 4 . A strong nuclear signal was disclosed in epidermal keratinocytes and endothelial cells. A weaker signal was observed in dermal dendritic cells. Probe omission and the anti-HSV probe gave consistently negative results.

\section{DISCUSSION}

The papulovesicular presentation and the widespread distribution of the lesions recalls varicella either of the primary or the recurrent type. However, the absence of general symptoms, the prolonged healing time, the age of the patients, the paucity and the larger diameter of the lesions, the concurrent chemotherapy for hemopathies, the same stage of development of all the lesions, and particularly the past primary varicella serologic $(\operatorname{IgG}+, \operatorname{IgM}-)$ status clearly distinguish the presently reported eruptions from typical childhood or adult primary varicella.

The pathomechanism of the presently reported lesions is puzzling. The clinical appearance VZV infection varies according to the site and type of infection in the skin. ${ }^{10,23-25}$ Hence, the vesicular type of herpes zoster has been associated with viral presence in the epidermal and pilosebaceous structures whereas the follicular (or papular) type reveals only viral expression in the epithelial cells of the pilosebaceous units. ${ }^{10,23-25}$ The wartlike expression of VZV infection in patients with AIDS is associated with a chronic, noncytolytic infection. ${ }^{10}$ However, the reported lesions do not correspond to herpes zoster, because of the absence of dermatomal distribution and zoster-associated pain so frequently observed in the elderly patient. 6,7 In contrast, besides epidermal involvement, histologic examination revealed vascular alterations with swollen endothelial cells. Immunohistochemistry and in situ hybridization evidenced VZV infection of endothelial cells. Although VZV is occasionally observed in endothelial cells during herpes zoster, ${ }^{24}$ the significant vascular changes suggest a vascular rather than neural origin of the lesions as has been documented for chicken- 
Table IV. Comparison of clinical features between primary varicella and recurrent varicella

\begin{tabular}{|c|c|c|c|c|c|}
\hline \multirow[b]{2}{*}{ Type } & \multicolumn{2}{|c|}{ Primary varicella } & \multicolumn{3}{|c|}{ Recurrent varicella } \\
\hline & Childhood & Adulthood & Childhood & Adults & Elderly patients \\
\hline Frequency & Frequent & Rare & Rare & Rare & ? (Underrecognize) \\
\hline $\begin{array}{l}\text { VZV serology } \\
\text { Underlying disorders }\end{array}$ & $\lg G-, \lg M+$ & $\lg G-, \lg M+$ & $\begin{array}{l}\operatorname{lgG}+, \lg M- \\
\text { HIV, cancer }\end{array}$ & $\begin{array}{l}\operatorname{lgG}+, \lg M- \\
\text { HIV, cancer }\end{array}$ & $\begin{array}{l}\lg +, \lg M- \\
\text { hemopathies }\end{array}$ \\
\hline No. of lesions & $>100$ & $>100$ & $>100$ & $>100$ & $10-40$ \\
\hline Disease course & Mild & Severe & Mild to severe & Severe & Mild \\
\hline Distribution of lesions & $\begin{array}{l}\text { Entire } \\
\text { tegumentum }\end{array}$ & $\begin{array}{l}\text { Entire } \\
\text { tegumentum }\end{array}$ & $\begin{array}{l}\text { Entire } \\
\text { tegumentum }\end{array}$ & $\begin{array}{l}\text { Entire } \\
\text { tegumentum }\end{array}$ & $\begin{array}{l}\text { Entire } \\
\text { tegumentum }\end{array}$ \\
\hline Lesion stage & All stages & All stages & All stages & All stages & Single stage \\
\hline Lesion diameter & $<1 \mathrm{~cm}$ & $<1 \mathrm{~cm}$ & $<1 \mathrm{~cm}$ & Variable & $1-4 \mathrm{~cm}$ \\
\hline $\begin{array}{l}\text { Cephalocaudal } \\
\text { progression }\end{array}$ & Yes & Yes & Yes & ND & NA \\
\hline Healing time of lesions & 5-8 days & ND & ND & Prolonged & 9-14 days \\
\hline $\begin{array}{l}\text { Delay between primary } \\
\text { and recurrent varicella }\end{array}$ & NA & NA & 5-17 months & months-years & $>30 y$ \\
\hline $\begin{array}{l}\text { No. of episodes of } \\
\text { recurrent varicella }\end{array}$ & NA & NA & $\begin{array}{c}\text { 1: } 34 \% \text { of } \\
\text { patients } \\
\text { 2: } 5 \%, \\
3-6: 1 \%-11 \%\end{array}$ & 1 & $\begin{array}{l}3 \text { relapses: } 1 \text { patient } \\
1 \text { relapse: } 3 \text { patients }\end{array}$ \\
\hline
\end{tabular}

$N A$, Not applicable; $N D$, no data.

pox. ${ }^{1,2}$ In fact, the secondary viremia of chickenpox infects the cutaneous endothelial cells after which the virus migrates (possibly by dermal dendritic cells) toward the epidermal keratinocytes producing a cytolytic infection. ${ }^{1,2}$ The VZV endothelial cell infection, the vascular changes, and the widespread distribution of the lesions constitute indirect clues for the presence of a viremia. Transient subclinical VZV viremia has been demonstrated in peripheral blood mononuclear cells of patients with herpes zoster, and in patients who are VZV seropositive (IgM-, IgG+) with no sign of VZV-related disease. ${ }^{26-28}$ In the latter patients, the viremic episodes remain probably subclinical as the patients are VZVseropositive and because of the paucity of viral load compared with that observed during varicella. ${ }^{27,28}$ On the other hand, previous vascular injury may create a predilective site for VZV replication, leading to varicella on photodamaged sites, ${ }^{29}$ or on other diverse skin injuries. ${ }^{30,31}$ Hence, in our patients, the chemotherapy could have damaged the endothelial cells, creating predilective sites for viral attachment and replication. However, this hypothesis is invalidated by the different time interval between the appearance of the lesions and the last chemotherapeutic course that varied from 5 days to 2 months (Table I).

Whether this particular type of recurrent varicella is specifically associated to malignant hemopathies or specific chemotherapeutic drug regimens remains to be determined by further observations.

Literature data9,10,14-21 and the current observa- tions are summarized in Table IV, highlighting specific differences between primary varicella in children and adults; and recurrent varicella in children, adults, and elderly patients. Primary varicella in children and adults can be distinguished from the recurrent type by the VZV-seronegative status. Furthermore, adult primary varicella differs from childhood chickenpox by its rarity, the more severe disease course, and the type of complications, involving preferentially the lung and liver compared with the neurologic complications in children. ${ }^{1,2}$ Currently reported cases can furthermore be separated from recurrent varicella in children and young adults by the age of the patients, the paucity of clinical lesions, the larger diameter of the lesions and their peculiar clinical aspect, the significantly longer time interval between primary varicella and the recurrence, the prolonged healing time of the lesions, the absence of a cephalocaudal progression of skin lesion appearance, their mild disease course, and the fact that all the lesions are in the same stage of development. This last point is in contrast with primary varicellla where typically erythematous, papular, vesicular, pustular, and crusted lesions are simultaneously observed.

The skin lesions cleared in all patients after intravenous acyclovir, using dosages recommended for patients with immunosuppression. The rationale of oral valacyclovir maintenance therapy is illustrated by the first patient in whom 3 successive episodes occurred. More case studies and evaluating of co- 
hort-based therapeutic management are needed to better mitigate this type of VZV recurrences.

In summary, the evidence of VZV infection in endothelial cells, the vascular alterations, and the widespread distribution of the lesions suggest that the reported eruptions are vascular rather than neural in origin. The aforementioned histologic and virologic findings, the recently published evidence of infraclinical viremia, ${ }^{27,28}$ the clinical differences with primary and relapsing varicella, and the absence of signs for herpes zoster suggest the diagnosis of atypical recurrent varicella. The atypical clinical presentation is probably bound to underrecognition. This study should increase awareness for atypical VZV manifestations and incite further virologic investigations in the event of unusual skin signs, especially in the immunocompromised host.

\section{REFERENCES}

1. Gelb LD. Varicella zoster virus. In: Fields BN, Knipe DM, et al, editors. Virology. 2nd ed. New York: Raven Press Ltd; 1990. p. 2011-54.

2. Arvin AM. Varicella zoster virus. Clin Microbiol Rev 1996;9:36181.

3. Sadzot-Delvaux C, Debrus S, Nikkels AF, Piette J, Rentier B. Varicella-zoster virus latency in the adult rat is a useful model for human latent infection. Neurology 1995;45:18-20.

4. Debrus S, Sadzot-Delvaux C, Nikkels AF, Piette J, Rentier B. Varicella-zoster virus gene 63 encodes an immediate-early protein that is abundantly expressed during latency. J Virol 1995;69:3240-5.

5. Mahalingham R, Wellsh M, Cohrs R, Debrus S, Piette J, Rentier B, et al. Expression of protein encoded by varicella-zoster virus open reading frame 63 in latently infected human ganglionic neurons. Proc Natl Acad Sci U S A 1996;93:2122-4.

6. Gilden DH, Mahalingam R, Dueland AM, Cohrs R. Herpes zoster: pathogenesis and latency. Prog Med Virol 1992;39:19-75.

7. McCrary ML, Severson J, Tyring SK. Varicella zoster virus. J Am Acad Dermatol 1999;41:1-14.

8. Heskel NS, Hanifin JM. "Recurrent herpes zoster": an unproved entity? J Am Acad Dermatol 1984;10:486-90.

9. von Seidlein L, Gillette SG, Bryson Y, Frederick T, Mascola L, Church J, et al. Frequent recurrence and persistence of varicellazoster virus infections in children infected with human immunodeficiency virus type 1. J Pediatr 1996;128:52-7.

10. Nikkels AF, Rentier B, Piérard GE. Chronic varicella-zoster virus skin lesions in patients with human immunodeficiency virus are related to decreased expression of $\mathrm{gE}$ and gB. J Infect Dis 1997; 176:261-4.

11. Nikkels AF, Snoeck R, Rentier B, Piérard GE. Chronic verrucous varicella-zoster virus skin lesions: clinical, histological, molecular and therapeutical aspects. Clin Exp Dermatol 1999;24:346-53.

12. Satoh N, Abe T, Nakajima A, Sakuragi S. Recurrent varicella-zos- ter virus retinitis in a patient treated with systemic corticosteroids. Ocul Immunol Inflamm 1998;6:185-8.

13. Nikkels AF. Piérard GE. Shingles developing within recent surgical scars. J Am Acad Dermatol 1999;41:309-11.

14. Srugo I, Israele V, Wittek AE, Courville T, Vimal VM, Brunell PA. Clinical manifestations of varicella-zoster virus infections in human immunodeficiency virus-infected children. Am J Dis Child 1993;147:742-5.

15. Leibovitz E, Cooper D, Giurgiutiu D, Coman G, Straus I, Orlow SJ, et al. Varicella-zoster virus infection in Romanian children infected with the human immunodeficiency virus. Pediatrics 1993;92:838-42.

16. Howarth CB. Recurrent varicella-like illness in a child with leukemia. Lancet 1974;10:342.

17. Donn SM, Dickerman JD. Fatal recurrent varicella in a child with acute lymphocytic leukemia. Am J Pediatr Hematol Oncol 1981; 3:183-5.

18. Suwabe $H$, Yabe $H$, Tsutsumi Y. Relapsing hemorrhagic varicella. Pathol Int 1996;46:605-9.

19. Acheson DW, Leen CL, Tariq WU, Mandal BK. Severe and recurrent varicella-zoster virus infection in a patient with the acquired immune deficiency syndrome. J Infect 1988;16:193-7.

20. Pitche $P, G$ badoe AE, Tidjani O, Tchangai-Walla K. Recurrent varicella and HIV infection: à propos of 10 cases seen in Lomé. Med Trop (Mars) 1997;57:65-7.

21. Baxter JD, DiNubile MJ. Relapsing chickenpox in a young man with non-Hodgkin's lymphoma. Clin Infect Dis 1994;18:785-8.

22. Nikkels AF, Delvenne P, Sadzot-Delvaux C, Debrus S, Piette J, Rentier $\mathrm{B}$, et al. Distribution of varicella zoster virus and herpes simplex virus in disseminated fatal infections. J Clin Pathol 1996; 49:243-8.

23. Nikkels AF, Debrus S, Sadzot-Delvaux C, Piette J, Rentier B, Piérard GE. Immunohistochemical identification of varicella zoster virus gene 63 encoded (IE63) and (gE) proteins on smears and cutaneous biopsies. J Med Virol 1995;47:342-7.

24. Nikkels AF, Delvenne P, Debrus S, Sadzot-Delvaux C, Piette J, Rentier B, et al. Distribution of varicella-zoster virus gpl and gpll and corresponding genome sequences in the skin. J Med Virol 1995;46:91-6.

25. Yi JY, Kim TY, Shim JH, Cho BK, Kim CW. Histopathologic findings, viral DNA distribution and lymphocytic immunophenotypes in vesicular and papular types of herpes zoster. Acta Derm Venereol 1997;77:194-7.

26. Feldman S, Chaudary S, Ossi M, Epp E. A viremic phase for herpes zoster in children with cancer. J Pediatr 1977;91:597-600.

27. Mainka C, Fuss B, Geiger H, Höfelmayr H, Wolff MH. Characterization of viremia at different stages of varicella-zoster virus infection. J Med Virol 1998;56:91-8.

28. Schünemann S, Mainka C, Wolff MH. Subclinical reactivation of varicella zoster virus in immunocompromised and immunocompetent individuals. Intervirology 1998;41:98-102.

29. Boyd AS, Neldner KH, Zemtsov A, Shihada B. Photolocalized varicella. J Am Acad Dermatol 1992;26:772-4.

30. Belhorn TH, Lucky AW. Atypical varicella exanthems associated with skin injury. Pediatr Dermatol 1994;11:129-32.

31. Wilkin JK, Ribble JC, Wilkin OC. Vascular factors and the localization of varicella lesions. J Am Acad Dermatol 1981;4:665-6. 